\title{
PENERAPAN PHP DAN MYSQL UNTUK MERANCANG SIM PENJUALAN BERBASIS WEB PADA PD BABY2GO
}

\author{
Gunawan Putrodjojo ${ }^{1}$ \\ Putu Handy Arjana ${ }^{2}$ \\ Edward $^{3}$ \\ ${ }^{1}$ Dosen STMIK Raharja, ${ }^{2,3}$ Mahasiswa STMIK Raharja \\ 1,2,3J1.Jendral Sudirman No.40,modern,Tangerang,021-5529692 \\ e-mail :gunawan.putrodjojo@raharja.info,putuha@yahoo.com,edwardokondo@gmail.com
}

\begin{abstract}
ABSTRAK
Perkembangan teknologi informasi (TI) yang semakin meluas membuat suatu perusahaan dituntut untuk menerapkan TI di berbagai aspek jika perusahaan tidak ingin tertinggal, tak terkecuali untuk PD. Baby2Go yang telah menerapkan penggunaan TI dengan memanfaatkan media sosial sebagai jalur bisnisnya. Meskipun telah menggunakan TI, dalam penerapannya masih terdapat masalah seperti sistem penjualan yang dikelola oleh divisi pemasaran saat ini membutuhkan waktu yang lama dalam pembuatan daftar pemesanan dan laporan penjualan, serta sulit mendapatkan laporan penjualan berdasarkan pengelompokan yang diinginkan oleh manajer seperti penjualan pada periode tertentu, ataupun penjualan berdasarkan pada data produk dan pelanggan. Selain itu, sistem yang berjalan saat ini tidak menjamin keamanan data yang disimpan. Informasi penjualan ini sangat berguna bagi manajer dalam membuat kebijakan-kebijakan demi kelangsungan hidup perusahaan.

Untuk mengatasi masalah ini, dibuatlah sebuah SIM Penjualan atau sistem informasi penjualan berbasis web dengan menggunakan bahasa pemrograman PHP dan database MySQL, untuk metode analisis menggunakan pendekatan analisis berorientasi objek dengan alat bantu UML (Unified Modelling Language), dan metode perancangan menggunakan SDLC (System Development Life Cylce). Sistem ini dapat menarik data penjualan yang disaring berdasarkan periode penjualan, nomor pemesanan, data produk, dan data pelanggan secara cepat.

Dengan dibuatnya SIM Penjualan ini, manfaat yang didapat adalah tersedianya informasi penjualan yang tepat waktu dan sesuai dengan kebutuhan manajer, serta memiliki keamanan data.
\end{abstract}

Kata Kunci: Sistem Informasi Penjualan, UML, SDLC, PHP, MySQL.

\section{PENDAHULUAN}

Perkembangan teknologi informasi saat ini sangat cepat meluas dan membawa perubahan-perubahan yang mendukung suatu hal untuk lebih maju, tak terkecuali pada kegiatan jual-beli secara online atau yang lebih dikenal dengan sistem $e$ commerce. Hal ini membuat kebutuhan akan sesuatu yang serba cepat, mudah, dan praktis selalu dituntut oleh setiap orang, khususnya dalam hal membeli suatu barang serta keakuratan informasi yang akan

Vol.2 No.1 - Februari 2016 
diterima, dan di sinilah peran teknologi itu diperlukan.

Perusahaan-perusahaan baik besar maupun kecil telah mengaplikasikan teknologi dan telah terbukti mendukung kinerja perusahaan menuju ke arah yang lebih baik. Tidak luput dari itu semua, teknologi informasi kini telah menjadi bagian hidup sehari-hari bagi mereka yang menggunakan dan memanfaatkannya. Walaupun teknologi informasi sudah sangat maju, tetap saja masih ada kekurangankekurangan yang harus diperbaiki dan dikembangkan sesuai dengan kebutuhan penggunanya.

Penerapan teknologi sudah dilakukan oleh PD. Baby2Go dengan mengandalkan media sosial sebagai jalur untuk mempromosikan dan menjual produk. Sistem yang telah berjalan saat ini dapat didukung dan dikembangkan dengan aplikasi berbasis web agar perusahaan dapat bersaing dengan perusahaan lain yang sejenis.

\section{PERMASALAHAN}

Permasalahan yang muncul pada PD. Baby2Go adalah sistem penjualan yang dikelola oleh divisi pemasaran saat ini membutuhkan waktu yang lama dalam pembuatan daftar pemesanan dan laporan penjualan, serta sulit mendapatkan laporan penjualan berdasarkan pengelompokkan yang diinginkan oleh manajer seperti penjualan pada periode tertentu, ataupun penjualan berdasarkan pada data produk dan pelanggan. Selain itu, sistem yang berjalan saat ini tidak menjamin keamanan data yang disimpan. Berdasarkan permasalahan pada divisi pemasaran, maka diusulkan sebuah sistem informasi penjualan berbasis web. Sistem ini diharapkan dapat memberikan informasi penjualan yang dibutuhkan oleh manajer secara akurat dan tepat waktu. Di samping itu dengan adanya sistem ini, mampu memberikan kemudahan bagi para pelanggan dalam melakukan pemesanan dan pembelian barang. Untuk PD. Baby2Go sendiri, sistem ini dapat memberikan daya saing dengan perusahaan lain yang sejenis.

\section{PEMECAHAN MASALAH}

Berdasarkan permasalahan yang telah disampaikan di atas, maka permecahan masalah yang dibahas adalah:

Lamanya proses pembuatan daftar pemesanan yang dilakukan dengan menginput satu per satu setiap transaksi yang ada dan disimpan di dalam file yang terpisah, sehingga ketika ingin membuat laporan penjualan, baik laporan penjualan bulanan ataupun laporan penjualan berdasarkan periode tertentu, staf pemasaran harus membuka banyak file. Begitu juga ketika membuat laporan penjualan berdasarkan pada data produk dan data pelanggan. Dengan cara seperti ini, tidak menutup kemungkinan terjadinya kesalahan penginputan.

Tidak adanya jaminan kemanan data karena data penjualan yang disimpan bisa saja diubah atau dihapus sewaktu-waktu oleh pihak yang tidak bertanggung jawab.

\section{TUJUAN}

Dari permasalahan yang telah disampaikan, artikel pada makalah ini bertujuan:

1. Mengenalkan dan menjelaskan arti pentingnya mempelajari Bahasa Pemrograman PHP dan Database MySql.

2. Mengetahui secara mendalam bagaimana SDLC (System Development Life Cycle) dapat diterapkan dalam membangun sistem. 
3. Membuat sebuah sistem informasi penjualan berbasis web untuk memperoleh informasi penjualan tepat waktu dan sesuai dengan kebutuhan manajer, serta memiliki keamanan data.

4. Manfaat yang ingin didapat adalah tersedianya informasi penjualan yang dan dapat berguna bagi manajer dalam membuat kebijakankebijakan demi kelangsungan hidup perusahaan.

\section{PEMBAHASAN}

\section{Gambaran umum perusahaan}

PD. Baby2Go merupakan sebuah perusahaan dagang yang memfokuskan kegiatan bisnisnya pada produksi dan penjualan sepatu bayi untuk umur satu bulan sampai tiga tahun, berdiri pada tahun 2012 dan beralamatkan di Jalan Raya Mauk Km. 4 Kelurahan Periuk, Kecamatan Periuk, Kota Tangerang, Provinsi Banten. Memiliki filosofi "kami percaya bahwa setiap langkah dari bayi anda mempunyai ceritanya masing-masing, dan begitu juga sepatu kami. Dimulai dari langkah pertama, bahan berkualitas terbaik kami meyakinkan bayi anda merasa nyaman dan terlihat indah, sehingga bayi anda dapat bergerak bebas kemanapun tanpa hambatan-hambatan."

\section{Sistem Yang Berjalan}

Dalam Sistem Berjalan terdapat uraian prosedur yang dijadikan acuab dalan menangani masalah .

1. Menangani pembelian dan respon pelanggan. Jika ada pelanggan yang ingin membeli produk, maka pelanggan tersebut akan melakukan komunikasi melalui media sosial dan menghubungi kontak pemesanan yang tertera pada media sosial. Staf pemasaran merespon pemesanan tersebut untuk meminta data pelanggan yang meliputi nama, nomor telepon, dan alamat pengiriman. Setelah didapat, pelanggan harus mentransfer pembayaran dan mengkonfirmasi pembayaran dengan mengirim foto bukti transfer. Lalu, staf pemasaran membuat dan mencetak dua rangkap daftar pemesanan, satu rangkap untuk divisi pemasaran sebagai arsip dan satu rangkap diberikan ke divisi produksi agar barang dikirimkan melalui ekspedisi.

2. Merekap dan memeriksa laporan penjualan. Staf pemasaran merekap data penjualan satu per satu di file yang terpisah berdasarkan daftar pemesanan yang ada dan memeriksanya sebelum diserahkan ke manajer pemasaran, jika dirasa sudah benar, maka diserahkan ke manajer pemasaran dalam bentuk laporan.

\section{Use case diagram sistem penjualan} Sistem

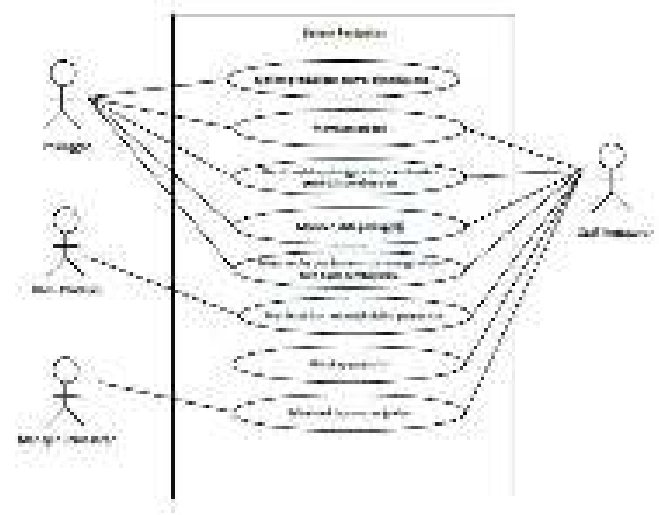

Gambar 1. Use Case Diagram Sistem Penjualan

Berdasarkan gambar 1. use case yang berjalan terdapat:

Satu sistem yang mencakup seluruh kegiatan penjualan.

Empat aktor yang melakukan kegiatan, yaitu Pelanggan, Divisi Produksi, Manajer Pemasaran, dan Staf Pemasaran.

\section{Vol.2 No.1 - Februari 2016}


Delapan use case yang biasa dilakukan oleh aktor-aktor.

\section{Activity diagram penjualan}

\section{a. Proses penjualan}

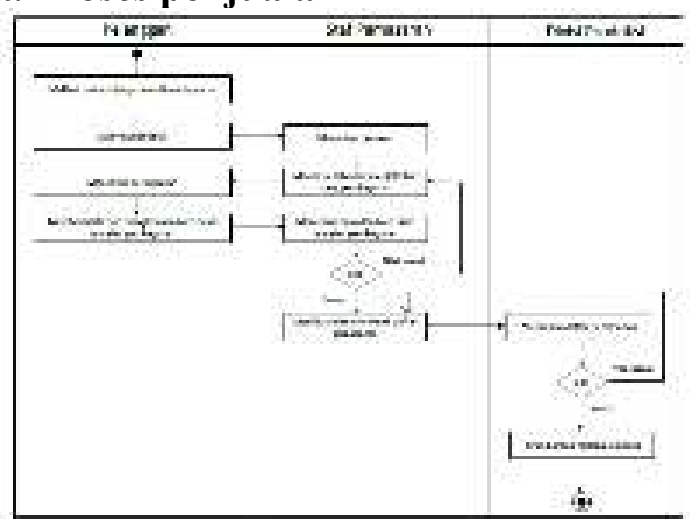

Gambar 2. Activity Diagram Proses Penjualan

Berdasarkan gambar 2. activity diagram yang berjalan terdapat:

1. Satu initial node sebagai awal objek.

2. Sepuluh action dari sistem yang mencerminkan eksekusi dari suatu aksi.

3. Dua decision yang menggambarkan kondisi sesuai atau tidaknya suatu aksi.

4. Tiga swimline sebagai inisial seseorang yang terdapat dalam sistem.

5. Satu final node sebagai objek yang diakhiri.

\section{b. Membuat laporan penjualan}

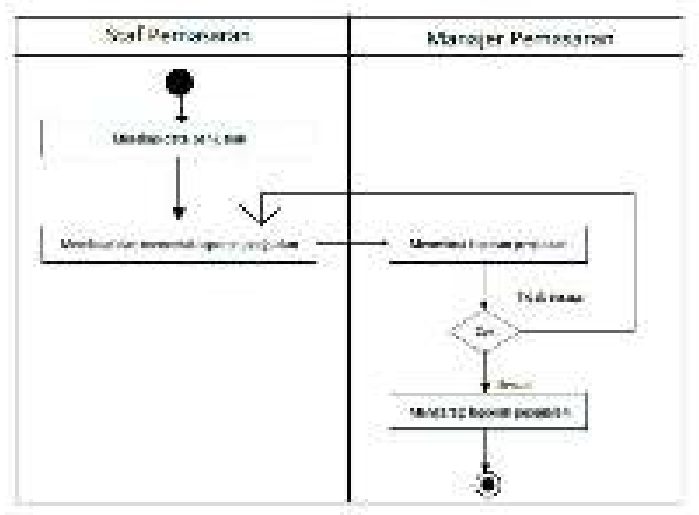

Vol.2 No.1 - Februari 2016
Gambar 3. Activity Diagram Membuat Laporan Penjualan

Berdasarkan gambar 3. activity diagram yang berjalan terdapat:

1. Satu initial node sebagai awal objek.

2. Empat action dari sistem yang mencerminkan eksekusi dari suatu aksi.

3. Satu decision yang menggambarkan kondisi sesuai atau tidaknya suatu aksi.

4. Dua swimline sebagai inisial seseorang yang terdapat dalam sistem.

5. Satu final node sebagai objek yang diakhiri.

\section{Usulan Sistem}

Usulan sistem yang diusulkan terdiri dari use case diagram, activity diagram, dan sequence diagram.

\section{Use case diagram yang diusulkan}

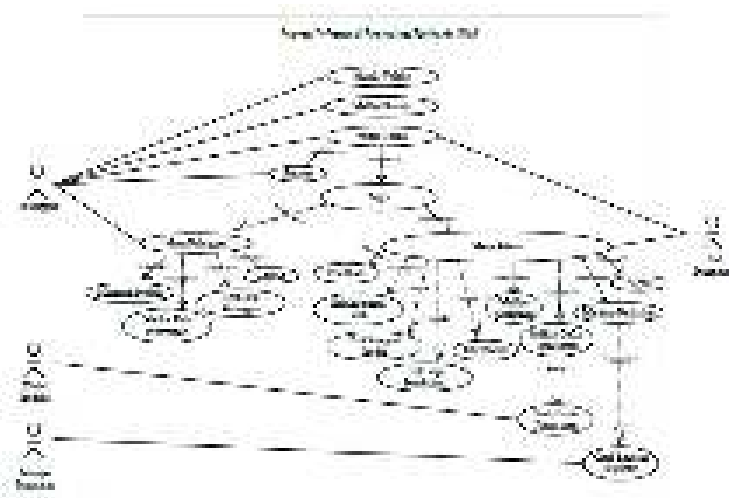

Gambar 4. usecase diagram usulan

Berdasarkan gambar 4. use case diagram yang diusulkan terdiri dari:

1. Satu sistem yang mencakup seluruh kegiatan penjualan berbasis web.

2. Empat aktor yang melakukan kegiatan, yaitu Pelanggan, Divisi Produksi, Manajer Pemasaran, dan Staf Pemasaran. 
3. total use case yang dilakukan oleh aktoraktor.

Activity diagram yang diusulkan

a. Mencetak daftar pemesanan

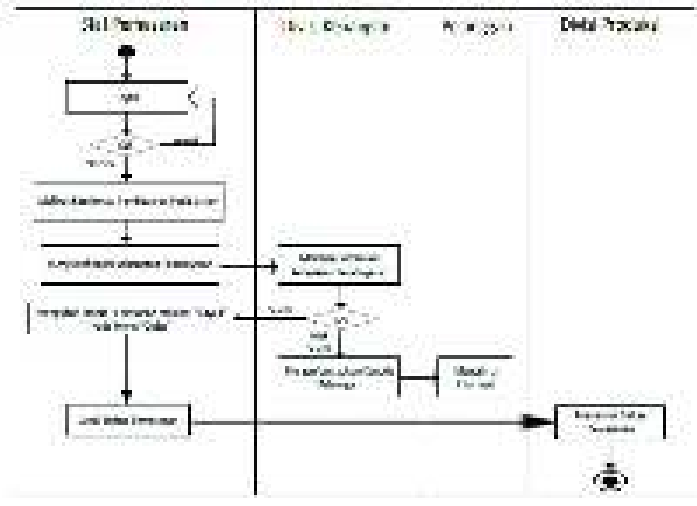

Gambar 5. Activity Diagram Mencetak Daftar Pemesanan

Berdasarkan gambar 5. activity diagram yang diusulkan terdiri dari:

1. Satu initial node sebagai awal objek.

2. Empat swimline sebagai inisial yang melakukan aktivitas.

3. Sembilan action dari keseluruhan swimline dalam sistem yang mencerminkan eksekusi dari suatu aksi.

4. Dua decision yang menggambarkan kondisi sesuai atau tidaknya suatu aksi.

5. Satu final node sebagai objek yang diakhiri

\section{Mencetak laporan penjualan}

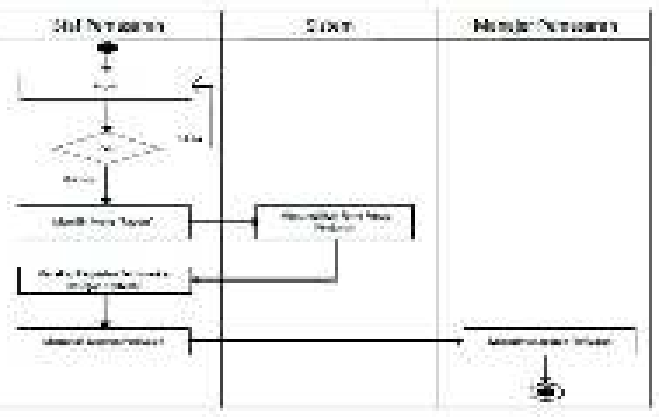

Vol.2 No.1 - Februari 2016
Gambar 6. Activity Diagram Mencetak Laporan Penjualan

Berdasarkan gambar 6. activity diagram yang diusulkan terdiri dari:

1. Satu initial node sebagai awal objek.

2. Tiga swimline sebagai inisial yang melakukan aktivitas.

3. Enam action dari keseluruhan swimline dalam sistem yang mencerminkan eksekusi dari suatu aksi.

4. Satu decision yang menggambarkan kondisi sesuai atau tidaknya suatu aksi.

5. Satu final node sebagai objek yang diakhiri.

Sequence diagram

Mencetak daftar pemesanan

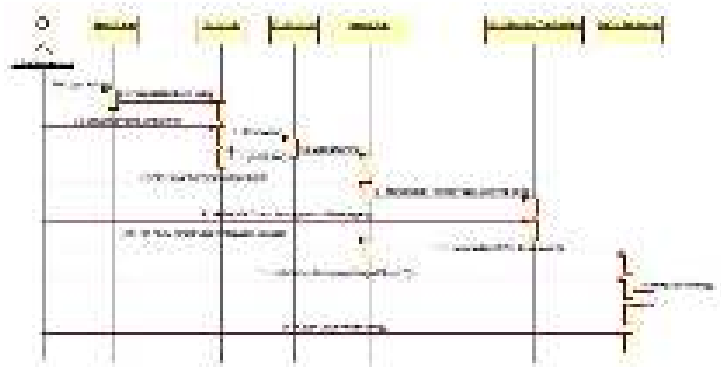

Gambar 7. Sequence Diagram Mencetak Daftar Pemesanan

Berdasarkan gambar 7. dijelaskan bahwa dalam proses mencetak daftar pemesanan yang dilakukan oleh staf pemasaran membutuhkan 14 message yang terdapat pada keseluruhan lifeline yaitu, menu utama, form login, control login, menu admin, form confirm the payment, dan daftar pemesanan. 


\section{Mencetak laporan penjualan}

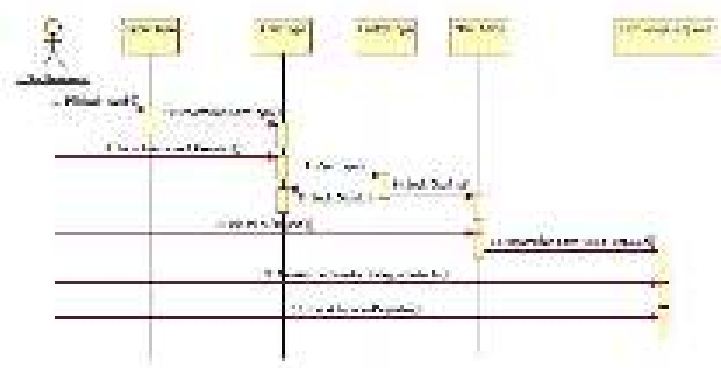

Gambar 8. Sequence Diagram Mencetak Laporan Penjualan

Berdasarkan gambar 8. dijelaskan bahwa dalam proses mencetak laporan penjualan yang dilakukan oleh staf pemasaran membutuhkan 10 message yang terdapat pada keseluruhan lifeline yaitu, menu utama, form login, control login, menu admin, dan form rekap penjualan.

\section{Rancangan class diagram}

Rancangan class diagram yang ada pada sistem dapat digambarkan sebagai berikut:

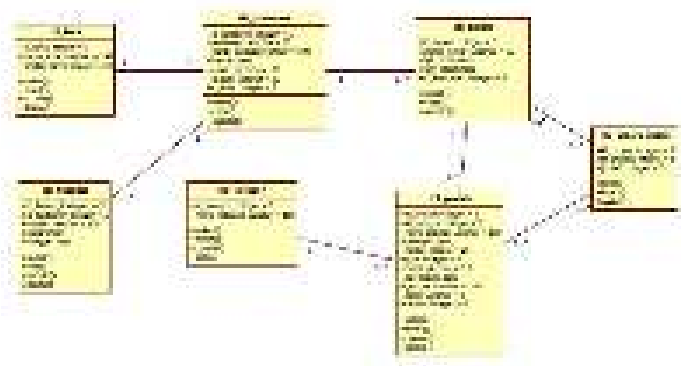

Gambar 9.. Rancangan Class Diagram

Berdasarkan gambar 9. dijelaskan bahwa dalam rancangan class diagram terdapat tujuh tabel yaitu, kota, hubungi, kustomer, kategori, orders, produk, dan orders detail. Simbol multiplicity 1..* menandakan adanya relasi satu kelas ke banyak kelas.

Vol.2 No.1 - Februari 2016

\section{Spesifikasi Basis Data}

Spesifikasi basis data yang ada pada sistem penjualan berbasis web dapat dijelaskan sebagai berikut:

1. Nama File : tbl_kustomer

Media : Sistem berbasis web

Isi :

Organisasi File : Index

Primary Key : id_kustomer

Panjang Record : 280

Type File : File pelanggan

Tabel.1. Tabel Kustomer

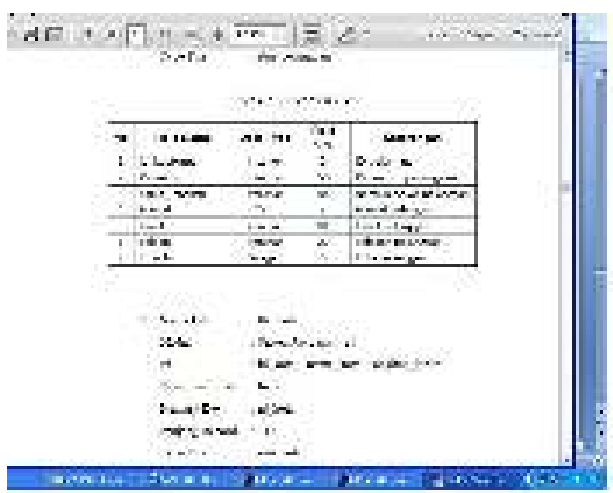

2. Nama File : tbl_kota

Media : Sistem berbasis web

Isi : id_kota + nama_kota + ongkos_kirim Organisasi File : Index

Primary Key : id_kota

Panjang Record : 113

Type File : File kota

Tabel.2. Tabel Kota

\begin{tabular}{|c|c|c|c|c|}
\hline No & Fale Yame & Does Typ & $\begin{array}{l}\text { Aold } \\
5 \mathrm{Su}\end{array}$ & terossegenn \\
\hline 3 & of wats & $1+1+w^{t}$ & 3 & 1) seis \\
\hline 2 & carre bors & sincher & 100 & Numb bors \\
\hline 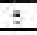 & serdesbibl & 1035 & 21 & Urdasonin \\
\hline
\end{tabular}

3. Nama File : tbl_produk Media : Sistem berbasis web 
Isi :

Organisasi File : Index

Primary Key : id_produk

Panjang Record : 245

Type File : File produ

\section{Tabel 3. Tabel Produk}

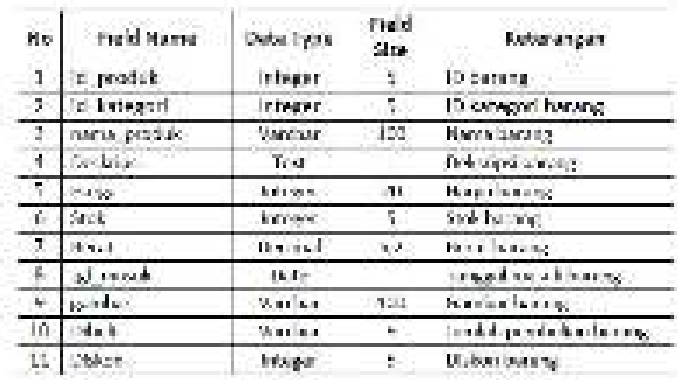

4. Nama File : tbl_kategori

Media : Sistem berbasis web

Isi : id_kategori + nama_kategori

Organisasi File : Index

Primary Key : id_kategori

Panjang Record : 105

Type File : File kategori

Tabel 4 Tabel Kategori

\begin{tabular}{|c|c|c|c|c|}
\hline his & Fls d karet & Doves Typs. & $\begin{array}{l}\text { Flobid } \\
\text { gin }\end{array}$ & Knerangs: \\
\hline 1 & II kaivgsal & itioger & $=$ & 15 latopar / astath \\
\hline 7 & $\mathrm{mmm}$ ksmps & Tomber & कn & Ginsterendhorn? \\
\hline
\end{tabular}

5. Nama File : tbl_orders

Media : Sistem berbasis web

Isi :

Organisasi File : Index

Primary Key : id_orders

Panjang Record : 60

Type File : File orders
Tabel .5. Tabel Orders

\begin{tabular}{|c|c|c|c|c|}
\hline $\begin{array}{l}\text { Ko } \\
1 \\
\end{array}$ & $\begin{array}{l}\text { Bisularre } \\
\text { id_ad_is. }\end{array}$ & 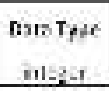 & $\begin{array}{l}\text { Ind } \\
\text { sine } \\
3\end{array}$ & 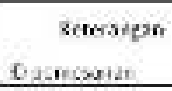 \\
\hline$z$ & Elist enth & sortur & $\$ 1$ & Status remrouran \\
\hline 4 & 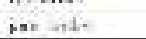 & TE. & & Audnoverats. \\
\hline 5 & W_kitoris: & risger & 5 & Vpabrazan \\
\hline
\end{tabular}

6. Nama File : tbl_orders_detail Media : Sistem berbasis web Isi : id_orders + id_produk + jumlah Organisasi File : Index Foreign Key : id_orders + id_produk Panjang Record : 15

Type File : File orders_detail

Tabel.6. Tabel Orders Detail

\begin{tabular}{|c|c|c|c|c|}
\hline$P \neq 0$ & Ficuldawe & asa Triso & $\begin{array}{l}\text { Fieb } \\
\text { ass }\end{array}$ & Koterargen \\
\hline 1 & $\begin{array}{l}\text { N_od:is } \\
i=\text { :mtik }\end{array}$ & $\begin{array}{l}\text { w.-.ed } \\
\text { moner }\end{array}$ & 5 & $\begin{array}{l}\text { Dp-rocssion } \\
\text { in tararg }\end{array}$ \\
\hline 5 & bondsi & $1+1=0$ & 3 & 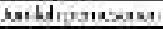 \\
\hline
\end{tabular}

7. Nama File : tbl_hubungi

Media : Sistem berbasis web

Isi :

Organisasi File : Index

Primary Key : id_hubungi

Panjang Record : 110

Type File : File hubungi

Tabel.7. Tabel Hubungi

\begin{tabular}{|c|c|c|c|c|}
\hline no. & Rals farme & Dentu Type & $\begin{array}{l}\text { Rel } \\
5=1\end{array}$ & Kaburkngke \\
\hline 1 & a_dobures & byss & 3 & tingerts \\
\hline 2 & Whanlats: & Horss & 3 & Exidassal \\
\hline 3 & $5=6 t a x$ & Unctor & 160 & 4athat parksกา \\
\hline$\therefore$ & Fean & Tast & : & Four \\
\hline 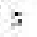 & Trevel & Cre & $\therefore$ & Terase \\
\hline
\end{tabular}

Literature Review

Penelitian yang dilakukan oleh Yulianti

(2009) Penelitian yang berjudul "PERANCANGAN SISTEM INFORMASI PENJUALAN PADA PT. FATRAPOLINDO NUSA INDUSTRI, 
TBK" ini, diusulkan untuk memperbaiki 48 kekurangan yang ada pada sistem yang berjalan. Sistem tersebut menggunakan bahasa pemrograman Visual Basic 6.0 untuk perancangan menu masukan dan penulisan kode program, untuk bentuk laporan menggunakan Crystal Report 8.0, dan Microsoft SQL Server 2000 sebagai database. Metode yang dipakai dalam pembuatan sistem ini adalah metode terstruktur seperti Data Flow Diagram, Context Diagram, Overview Diagram, dan diagram rinci. Kelebihan yang dihasilkan dari sistem ini adalah memudahkan karyawan dalam melakukan penginputan dan pengontrolan data.

Penelitian yang dilakukan oleh Lia Permata Sari (2010) Penelitian yang berjudul "PERANCANGAN PROGRAM APLIKASI PENJUALAN PADA PT. IRAMA JAYA" ini, diusulkan untuk memperbaiki kekurangan yang ada pada sistem yang berjalan. Sistem tersebut menggunakan bahasa pemrograman Visual Basic 6.0 untuk perancangan menu masukan dan penulisan kode program, Microsoft $S Q L$ Server 2000 sebagai database, dan sistem operasi menggunakan Microsoft Windows $X P$. Metode yang dipakai dalam pembuatan sistem ini adalah metode terstruktur seperti Data Flow Diagram, Context Diagram, Overview Diagram, dan diagram rinci. Kelebihan yang dihasilkan dari sistem ini adalah meningkatkan efisiensi dan efektifitas dalam hal pencarian informasi barang, pencatatan transaksi penjualan barang-barang elektronik, dan dalam pembuatan laporan penjualan.

Penelitian yang dilakukan oleh Meylina (2010) Penelitian yang berjudul "PERANCANGAN PROGRAM APLIKASI PENJUALAN KREDIT MOBIL BEKAS KING AUTO GALLERY" ini, diusulkan untuk memperbaiki 49 kekurangan yang ada pada sistem yang berjalan. Sistem tersebut menggunakan bahasa pemrograman
Visual Basic 6.0 untuk perancangan Graphical User Interface (GUI) dan penulisan kode program, untuk laporan dibuat dengan menggunakan program aplikasi Crystal Report 8.5, dan untuk database menggunakan Microsoft Access. Metode yang dipakai dalam pembuatan sistem ini adalah metode terstruktur seperti Data Flow Diagram, Context Diagram, Overview Diagram, dan diagram rinci. Kelebihan yang dihasilkan dari sistem ini adalah mendapatkan pengelolaan data yang baik bagi direktur maupun karyawan, dan memudahkan dalam menginput data pembeli, mobil, pemesanan, dan penghitungan kredit.

Penelitian yang dilakukan oleh Nita Wijayanti (2011) Penelitian yang berjudul "PERANCANGAN SISTEM INFORMASI PENJUALAN KOMPONEN PANEL BUILDER PADA PT. MUNHEAN PUMA PERKASA" ini, diusulkan untuk memperbaiki kekurangan yang ada pada sistem yang berjalan. Sistem tersebut menggunakan bahasa pemrograman Visual Basic 6.0 untuk perancangan menu masukan dan penulisan kode program, untuk database menggunakan Microsoft Access 2003, dan sistem operasi menggunakan Microsoft Windows 7. Metode yang dipakai dalam pembuatan sistem ini adalah metode terstruktur seperti Data Flow Diagram, Context Diagram, Overview Diagram, dan diagram rinci. Kelebihan yang dihasilkan dari sistem ini adalah mempermudah dalam melakukan pengelolaan transaksi penjualan.

Penelitian yang dilakukan oleh Kathy Octavia (2012) Penelitian yang berjudul "PERANCANGAN SISTEM INFORMASI PENJUALAN FURNITURE PADA PT. ALBA UNGGUL METAL" ini, diusulkan untuk memperbaiki kekurangan yang ada pada sistem yang berjalan. Sistem tersebut menggunakan bahasa pemrograman Visual Basic.NET, database menggunakan Microsoft SQL Server 2005, dan sistem operasi menggunakan Microsoft Windows

Vol.2 No.1 - Februari 2016 
$X P$. Metode yang dipakai dalam pembuatan sistem ini adalah metode terstruktur seperti Data Flow Diagram, Context Diagram, Overview Diagram, dan diagram rinci. Kelebihan yang dihasilkan dari sistem ini adalah mempermudah dalam melakukan penginputan data, perhitungan data, dan menghasilkan laporan keuangan.

\section{Rancangan Dialog Layar}

Rancangan dialog layar sistem dijabarkan sebagai berikut:

\section{Menu utama}

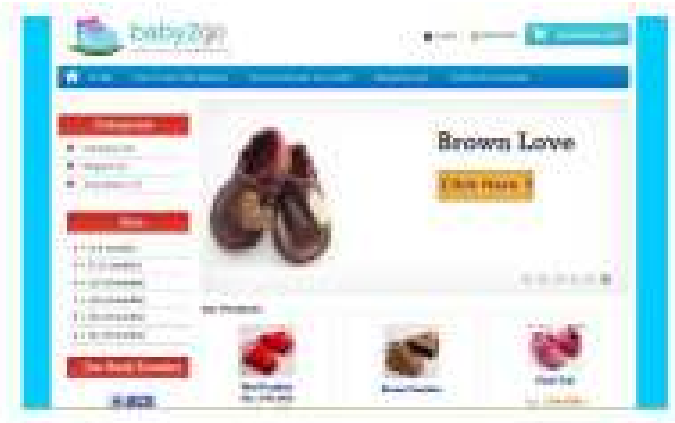

Gambar 10. Menu Utama

Layar ini menyajikan gambaran umum dari PD Baby2Go. Menyajikan informasi umum dari PD.

\section{Menu produk}

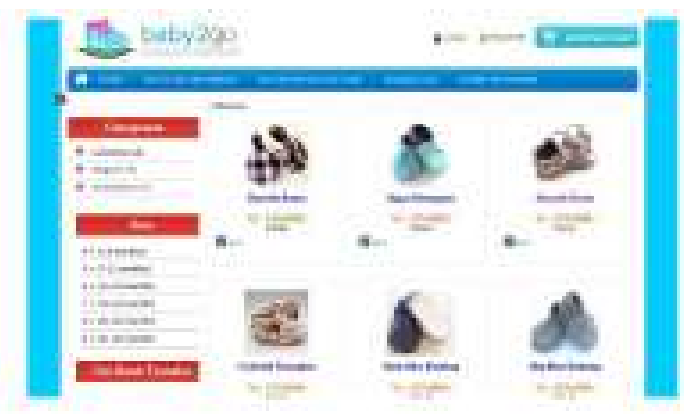

Gambar 11. Menu Produk

Layar ini menampilkan produk-produk yang ditawarkan oleh PD Baby2Go. Apa saja yang bisa dibeli oleh pelanggan dapat dilihat disini. Baik jenis maupun model dan spesifikasi sampai ke warna detail produk dapat dilihat disini.

\section{Menu register}

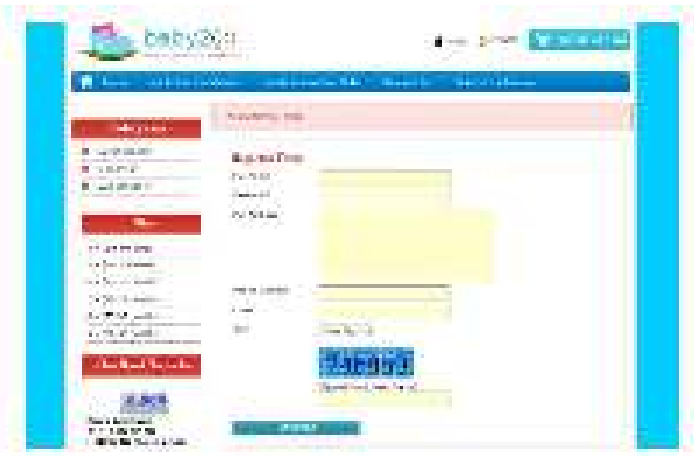

Gambar 12. Menu Register

Bagi pelanggan yang belum melakukan registrasi dapat menggunakan login register pada layar ini. Tentu saja data pelanggan dapat dimasukkan disini.

\section{Menu login pelanggan}

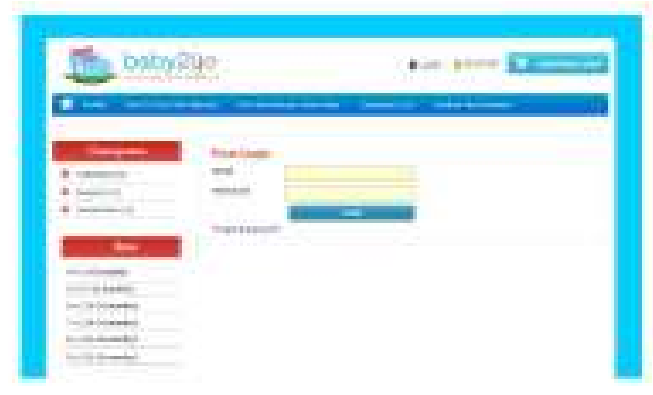

Gambar 13. Menu Login Pelanggan

Pada layar Registster, pelanggan diminta untuk sekali saja melakukan register. Pada layar ini Pelanggan diminta melakukannya pada setiap mau melakukan transaksi. Artinya apabila hendak melakukan pemesanan produk maka pelanggan wajib mengisi atau login di layar ini. 


\section{Menu login admin}

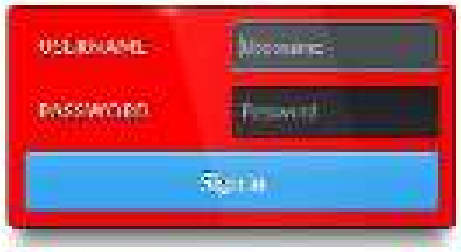

Gambar 14. Menu Login Admin

Menu ini digunakan oleh Admin untuk masuk pada menu-menu yang dia miliki.

\section{Menu pelanggan}

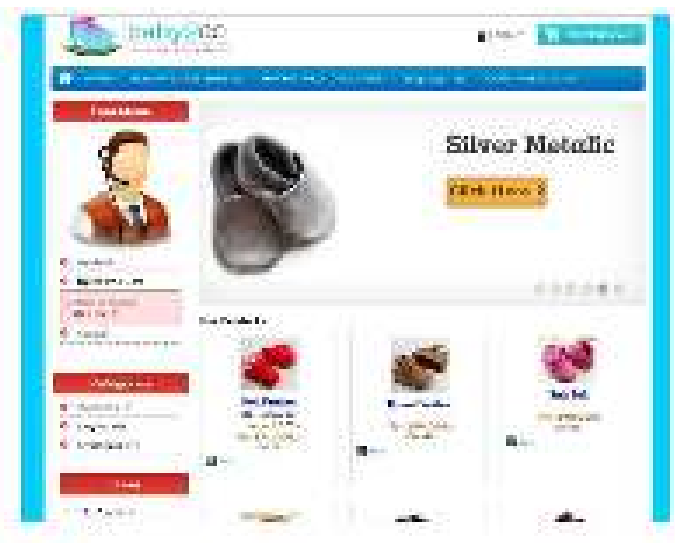

Gambar 15. Menu Pelnggan

Menu ini digunakan oleh pelanggan untuk memilih produk-produk yang hendak dibeli.

\section{Aplikasi yang digunakan}

Aplikasi yang digunakan dalam pembuatan sistem penjualan berbasis web ini dijabarkan sebagai berikut:
a. Sistem operasi Windows 8.1
b. Microsoft Office 2013
c. Mozilla Firefox
d. Adobe Dreamweaver CS3
e. Xampp
f. StarUML

\section{Konsep dasar PHP}

Menurut (Rudyanto Arief, 2011: 43) PHP adalah bahasa server-side scripting yang menyatu dengan HTML untuk membuat halaman web yang dinamis. PHP dirancang untuk membentuk halaman web yang dinamis, yaitu halaman web yang dapat membentuk suatu tampilan berdasarkan permintaan terkini, seperti menampilkan isi basis data ke halaman web.

\section{MySQL}

Menurut Bunafit Nugroho (dalam Nenden, 2014: 45) MySQL (My Structured Query Language) adalah sebuah program pembuat dan pengelola database atau yang sering disebut dengan DBMS (Database Management System). Sifat dari DBMS ini adalah open source.

Beberapa kelebihan database MySQL antara lain:

MySQL merupakan database server, jadi dapat diakses dari jauh karena dapat tersambung ke media internet selain itu juga dapat berperan sebagai client.

MySQL adalah sebuah software data open source artinya software ini bebas digunakan oleh siapa saja tanpa harus membeli lisensinya kepada pembuat.

MySQL adalah database menggunakan enkripsi password, jadi cukup aman karena memiliki password untuk mengaksesnya.

MySQL merupakan database yang multi user, artinya database ini tidak hanya digunakan oleh sepihak orang akan tetapi dapat digunakan oleh banyak pengguna.

MySQL menggunakan suatu bahas permintaan standar yaitu SQL (Structured Query Language) yaitu sebuah perintah yang di standarkan pada database server.

\section{Testing}

Dalam penelitian ini, metode pengujian yang digunakan adalah Black Box Testing yang berfokus pada kebutuhan software. Pengujian ini dapat dijelaskan sebagai berikut: 


\section{Testing gagal register}

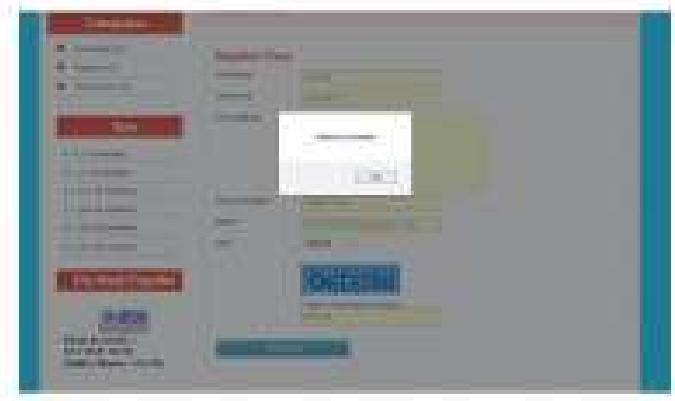

Gambar 16. Gambar testing gagal register

Berdasarkan gambar 16. dijelaskan bahwa kolom alamat sengaja tidak diisi, kemudian langsung menekan button "Register", maka hasilnya adalah sistem akan menolak dan memunculkan pesan "Address is required" yang menunjukkan bahwa kolom alamat harus diisi.

\section{Testing berhasil register}

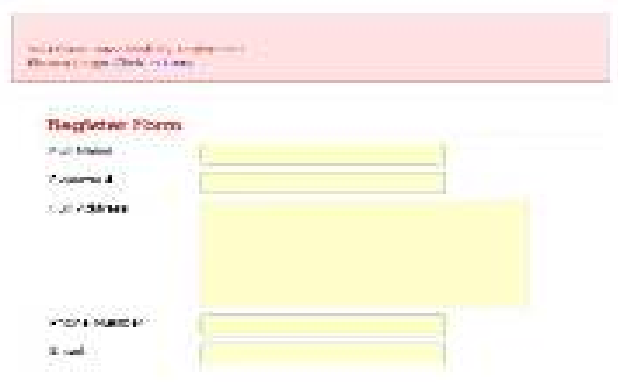

Gambar 17. Gambar berhasil register

\section{Testing gagal login}

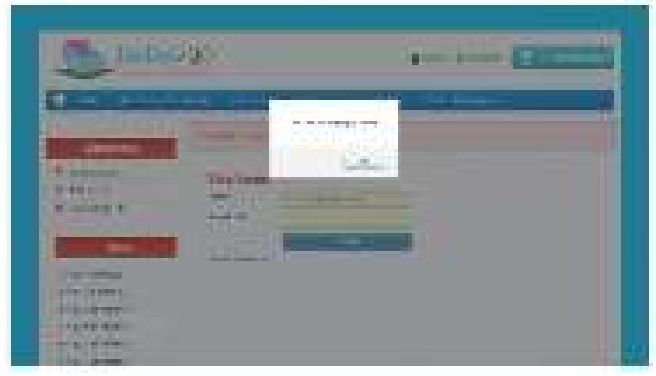

Gambar 18. Gambar gagal login

Berdasarkan gambar 18. dijelaskan bahwa kolom password sengaja tidak diisi, kemudian langsung menekan button
"Login”, maka hasilnya adalah sistem akan menolak dan memunculkan pesan "You are not fill the password" yang menunjukkan bahwa kolom password harus diisi.

\section{Testing berhasil login}

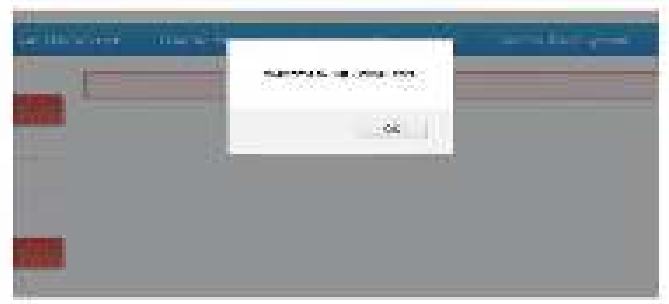

Gambar 19. Gambar berhasil login

Gambar 19. menunjukkan pesan ketika berhasil melakukan login, yaitu "Welcome to Our Online Store”.

\section{Kesimpulan}

Berdasarkan dari hasil percobaan dan implementasi sistem penjualan berbasis web terhadap kebutuhan perusahaan, dapat ditarik beberapa kesimpulan, yaitu:

1. Sistem mampu membuat daftar pemesanan secara cepat dan otomatis dimana daftar pemesanan yang ada terbentuk ketika pelanggan melakukan proses pemesanan pada sistem penjualan berbasis web. Dengan demikian, admin tidak perlu lagi membuat daftar pemesanan satu per satu.

2. Sistem menyimpan semua transaksi penjualan ke dalam satu file database, sehingga memudahkan sekaligus mempercepat admin ketika akan merekap dan membuat laporan penjualan tanpa harus membuka banyak file yang terpisah.

3. Sistem menyediakan pilihan untuk mengelompokkan transaksi penjualan yang ada sesuai kategori yang dibutuhkan.

Vol.2 No.1 - Februari 2016 
Dengan demikian, ketika admin akan merekap penjualan, maka admin dapat mengelompokkannya berdasarkan periode, nomor pemesanan, produk, dan pelanggan.

4. Sistem menyimpan semua data yang ada di dalam database dan diakes oleh satu admin, sehingga dapat menjamin keamanan data.

\section{DAFTAR PUSTAKA}

[1] Adi., N., (2010). Analisis dan Perancangan Sistem Informasi dengan Metodologi Berorientasi Objek, Edisi resmi, Informatika, Bandung.

[2] Esa, W., E., (2014), Perancangan Sistim Informasi Absesnsi Pegawai pada Kantor Kecamatan Batuceper Tangerang berbasis web.

[3] Foni, A., S., (2-12), Pemrograman Internet, ed. 1, Graha Ilmu, Yogjakarta,.

[4] Irwan, I., (2012) Reengineering Sistem Informasi, ed. 1, Graha Ilmu, Yojakarta.

[5] Mulyadi, (2008), Sistem Akutansi, ed. 3, Salemba empat.

[6] Murhada dan Yo, C., G,. (2011), Pengantar Teknologi Informasi, Mitra Wacana Media, Jakarta.

[7] Rudyanto, A., (2012), Pemrograman web dinamis menggunakan PHP \& Mysql, C.V. Andi offset, Yogjakarta.

[8] Semiawan, (2010), Metode Penelitian Kualitatif, Grasindo, Jakarta.

[9] Siti, A dan Nawang, K., (2011), Perancangan Aplikasi Akademik Teknologi Mobile menggunakan J2Me, Jurnal CCIT Vol. 4- no. 2, Januari 2011.

[10] Sucipto, (2011), Konsep dan Teknik Pengembangan Sistem berbasis Teknologi Informasi, Dinas Pendidikan Propinsi Banten.

Vol.2 No.1 - Februari 2016
[11] Sulistiyowati, I.. (2010), Pengaruh Profitabilitas Leverage dan Growth terhadap Kebijakan Deviden dengan Good Corporate Governance sebagai Variabel interveningf, Simposium Nasional Akuntansi XIII, Purwokerto.

[12] Sutarman, (2012), Komponen Sistem Informasi, Andi Offset, Yogjakarta.

[13] Tata, S., (2012) Konsep Sistem Informasi, C.V. Andi Offset, Yogjakarta.

[14] Tatik, S., (2013), Perilaku Konsumen di Era Internet, ed. 1, Graha Ilmu, Yogjakarta.

[15] Verdi, Y., (2012) Rekayasa Perangkat Lunak Berorientasi Objek Pemodelan Arsitektur dan Perancangan, Mitra Wacana Media, Jakarta.

[16] Yuhefixar, (2012), Cara mudah \& Murah membangun \& Mengelola wesite, ed. 1, Graha Ilmu, Yogjakarta. 